\title{
(2) Working Capital Management and Profitability ABe of Manufacturing Sector of Bangladesh: A Research House Causal Relationship
}

\author{
Kashfia Haque Neelom*, Suzona Asad \\ Lecturer, FBA, Eastern University, Dhaka, BANGLADESH \\ *E-mail for correspondence: kashfiahaque.fba@easternuni.edu.bd
}

Received: Dec 19, 2016;

Accepted: Mar 31, 2017;

Published: May 02, 2017

Source of Support: Nil

No Conflict of Interest: Declared

\begin{abstract}
This paper explores the causal relationship between working capital management and corporate profitability of manufacturing sector of Bangladesh. Sample data is composed of 21, Dhaka Stock Exchange (DSE) listed companies of Bangladesh, of four different industries from the year 2011 to 2015 . A multivariable model has been developed to examine the association between profitability and the working capital management. In the analysis, current ratio and debt ratio have been used as control variables. The findings clearly indicate a negative relationship between working capital management and profitability in the overall manufacturing sector as well as in each of these four industries and significance level varies from industry to industry.
\end{abstract}

Keywords: Working capital management, Cash conversion cycle, and ROA

\section{INTRODUCTION}

Working capital management is one of the most raising concepts for the financial managers because working capital is like the lifeblood of a firm (Scherr, 1989). Working capitals have a direct impact on the liquidity and profitability of any firm. If a business has some complimentary amount of working capital, then it is expected that it will always get the return on any favorable opportunity (Sial and Chaudhry, 2012). Managers spend much time on day-to-day problems that involve working capital decisions. Management of working capital generally means handling current assets and current liabilities (Garcia-Teruel PJ, Martinez-Solano PM, 2007). Current asset is essential for manufacturing firms as current assets is usually almost half of total assets for any manufacturing firm (Raheman A, Nasr, 2007). So properly managing the working capital means efficient use of current asset and current liabilities that helps to minimize risk of inability to fulfill the short term loans and best utilization of current assets to maximize the current opportunities. This study examines the extent of dependency of profitability over the working capital components of manufacturing firms of Bangladesh.

\section{LITERATURE REVIEW}

Working capital management plays a vital role in creating value for shareholders (Shin HH, Soenen L, 1998). It is a growing research topic for researchers all over the world. Many studies have been conducted regarding whether there is a relationship between working capital management and profitability of a company. Some researchers have found a positive association between working capital management and profitability, but some have got a negative or no relationship.

Many of prior research results have proved the significance of working capital management for a better profitability of the firm. Lazaridis and Tryfonidis (2006), found a positive association between working capital management efficiency and profitability. Greek researcher Deloof (2003) stated that the way that working capital is managed has a significant effect on the profitability of Belgian firms. Cote and Latham (1999) argued that handing of inventory, account receivables, and accounts payable have a tremendous impact on cash flows, and thus have effect on the profitability of firms. Long, Malitz and Ravid (1993) found that liberal credit terms and conditions to the customers results in increased sales level of the firm, though they face problems in managing short-term financing. Raheman and Naser (2007) found that Pakistani firms' performance showed a significant relationship with the profitability and working capital management. Scherr (1989, p. 16) concluded that companies could reinforce strong cash flow levels, budgeting, improve profitability and even predictability or manageability if they can implement the best policies in working capital. Siddiquee and Khan (2008) has found that firms that are better at managing working capital are better in making cyclical moves to create competitive advantage, and at 
generating fund internally and even in seeking external sources of financing as well.

Though many studies have been made regarding the relationship between profitability and working capital management, no recent study has been conducted regarding this issue on the perspective of manufacturing sector of Bangladesh. Moreover, from the best of our knowledge, no study has been conducted on the textile sector of Bangladesh. So in this study the relationship and the extent of relationship between working capital management and profitability are found in the current context including the backbone of Bangladesh.

\section{Research Methods}

\section{Data Collection}

This study is based on secondary sources that are the company's audited annual reports. The samples are drawn from the listed firms of Dhaka Stock Exchange (DSE). Four manufacturing industries have been selected to collect the data for this study. The sample industries were selected by judgmental sampling. According to DSE, there are ten manufacturing industries among which four industries were finalized. The selected industries are- cement, food, pharmaceutical, and textile. While drawing samples, it is emphasized that the samples cover all sizes of firms regarding capital and sales. The rationalization of taking DSE listed companies is that companies Security Exchange listed firms are likely to follow a formally regulated audit process and have an incentive to attract new investors and make an impression by presenting actual profits, if those exist, to make their shares more attractive. By contrary, firms not listed on the stock exchange are less trustworthy, have less incentive to present accurate operational results and have a tendency to conceal true profit to avoid corporate tax, as according to Lazaridis and Tryfonidis (2006). For food, pharmaceutical and textile industries five companies are selected out of DSE enlisted 18 firms in food, 28 firms in pharmaceutical, 45 firms in textile industry and finally six companies are selected from 7 companies of cement industry. Therefore, the sample size is 21 firms $(n=21)$ from the four industries. Moreover, the calculation period of the study is from the year 2011 to the year 2015.

\section{Research Model and Hypotheses}

Correlation and regression analysis is done for overall industries or DSE, to study the relationship between working capital management efficiency and profitability. For identifying the industry-wise impact of working capital management on profitability, industry wise multiple regressions are also done as well as correlation. For the regression analysis, a multivariable model has been developed, where profitability ratios are considered as the dependent variable and vital working capital ratios and liquidity ratios are selected as independent variables. Here, cash conversion cycle is used to measure the performance of working capital management, likewise found in Raheman and Nasr (2007), Lazaridis and Tryfonidis
(2006). To determine profitability, return on asset (ROA) is used. ROA is one of the vital measures of profitability, irrespective of the percentage of leverage in the capital structure of the company. Besides ROA, all other variables are independent variables. Following are all the variables chosen and their methods used for calculation:

- $\quad$ Return On Asset (ROA) Net Profit / Total Asset

- Receivables Collection Period (RCP) 360 / (Sales/ Accounts Receivables)

- Inventory Turnover Period (ITP) 360 / (COGS / Inventory)

- Payable Deferral Period (PDP) 360 / (COGS / Accounts Payable)

- Cash Conversion Cycle (CCC) RCP + ITP - PDP

- Current Ratio (CR) Current Assets/ Current Liabilities

- $\quad$ Debt Ratio (DR) Total Debts/ Total Assets

These independent variables mentioned above are the very fundamental measures of working capital efficiency and liquidity of a firm.

All the variables listed above are expressed as ratios or proportions except for cash conversion cycle and its components. These variables have days as a unit.

Correlation and Regression tests are conducted, to analyze the nature and extent of the relationship. The dependent variables are regressed against the independent variable.

The following equation is initially developed to estimate the impact of working capital management on the profitability measures:

\section{$R O A$ it $=\beta 0+\beta 1$ (ACP it) $+\beta 2($ APP it $)+\beta 3$ (ITIDit) + $\beta 4(C C C$ it $)+\beta 5($ DRit $)+\beta 6(C R$ it $)+\varepsilon \quad$ (Equation-3.2.1)}

As Cash Conversion Cycle $(C C C)=$ No of Days $A / R+$ No of Days Inventory - No of Days $A / P$ The Model was re-written and CCC is taken as representative of working capital variables to avoid the problem of multicollinearity as follow:

\section{$R O A$ it $=\beta 0+\beta 1(C C C$ it $)+\beta 2(C R$ it $)+\beta 3(D R$ it $)+\varepsilon$ (Equation-3.2.2)}

Where,

ROA it $=$ Return on Assets of firm $\mathrm{i}$ at time $\mathrm{t}, \mathrm{i}=1,2, \ldots \ldots, \mathrm{n}$ firms.

$\beta 0$ : The intercept of the equation

$\beta \mathrm{i}$ : Coefficients of independent variables

$t$ : Time $=1,2, \ldots \ldots, 5$ years.

$\varepsilon$ : The error term

ROA: Return on Assets

ACP: Average Collection Period

ITID: Inventory Turnover in Days

APP: Average Payment Period

CCC: Cash Conversion Cycle

CR: Current Ratio

DR: Debt Ratio 


\section{Hypotheses}

$\mathrm{H}_{1}$ : There is a negative relationship between Average Collection Period and ROA.

$\mathrm{H}_{2}$ : There is a negative relationship between Inventory turnover in days and ROA.

$\mathrm{H}_{3}$ : There is a positive relationship between Average Payment Period and ROA.

$\mathrm{H}_{4}$ : There is a negative relationship between Cash Conversion Cycle and Return on Asset.

$\mathrm{H}_{5}$ : There is a negative relationship between Debt Ratio and Return on Asset.

$\mathrm{H}_{6}$ : There is a positive relationship between Current Ratio and Return on Asset.

\section{ANALYSIS}

\section{Pharmaceutical Industry}

In the present study, Pearson Correlation is used to find out the nature of the relationship between variables. Table 1.1 of Appendices shows the correlation matrix for the variables of the pharmaceutical industry.

To have further investigation about the extent of the relationship and reliability of the result, regression analysis also has been done for pharmaceutical industry. In Table 1.2 from Appendices, it is found that ROA has insignificant relationship with $\mathrm{CR}$ and $\mathrm{DR}$. It has the only significant relationship with cash conversion cycle. ROA is negatively correlated with the cash conversion cycle, which means that the shorter the cash conversion cycle, better is the ROA. The regression equation for variables that do not show the significant relationship with the dependent variable have been excluded in this section. The equation for statistically significant variables that resulted out of the test is as below:

ROAP $=0.328-0.001 \mathrm{CCC}$

In the above equation, $\mathrm{p}$ indicates pharmaceutical industry and from the equation, it can be stated that for 1 unit increase in CCC, ROA will be decreased by 0.001 units. The Table 1.2 shows that R-square of the pharmaceutical industry is 0.35 , which means the ROA of pharmaceutical industry varies 0.35 or $35 \%$ due to the change in the cash conversion cycle.

\section{Food Industry}

Table 2.1 of Appendices shows the correlation matrix for the variables of the food industry. Regression analysis has been done for food industry to know about the level of the relation between variables. In Table 2.2 of Appendices, regression analysis of food industry has been demonstrated. From the table, it is found that ROA has insignificant relationships with CR and DR in the food industry as well. It has the only significant relationship with cash conversion cycle. ROA is negatively correlated with the cash conversion cycle, which means that the shorter the cash conversion cycle, the more is the ROA. In the regression equation, variables that did not show the significant relationships with the dependent variable have not been included in this section. The equation for food industry can be shown like this:

\section{ROAF $=0.335-0.001 \mathrm{CCC}$}

In the above equation, $\mathrm{F}$ denotes food industry. And, the equation shows that for 1 unit increase in CCC, there will be 0.001 unit decrease in ROA of the food industry. Table 2.2 illustrates that R-Square of food industry is 0.451 which means that the model fits by .451 or $45.1 \%$.

\section{Textile Industry}

Table 3.1 of Appendices shows the correlation matrix for the variables of the textile industry. And, table 3.2 of appendices shows the regression analysis for textile industry. In Table 3.2 of Appendices, regression analysis of food industry has been shown. From the table, it is found that ROA has an insignificant relation with DR in the textile industry. However, it has the significant relationships with cash conversion cycle and CR. ROA is negatively correlated with the cash conversion cycle, which means if the cash conversion cycle is lower, then ROA will be higher. And, CR has a significant positive relationship with ROA, which means if the currents asset on hand increase, then the ROA will also increase. Here it can be assumed that more the company purchases inventory, the better is the return on asset for the industry. In the regression equation, variables that do not show the significant relationships with the dependent variable have been excluded in this section. The equation for statistically significant variables that resulted out of the test is as below:

\section{ROAT $=0.041-0.001 \mathrm{CCC}+0.062 \mathrm{CR}$}

In the above equation, $\mathrm{T}$ denotes the textile industry. And, the equation shows that for 1 unit increase in CCC, there will be 0.001 unit decrease in ROA of the textile industry and for 1 unit increase in current ratio, ROA will be increased by 0.62 units. Table 3.2 shows that $R$-square of the textile company is 0.614 which means that the model fits by $61.4 \%$

\section{Cement Industry}

Table 4.1 of Appendices shows the correlation matrix for the variables of cement industry. Regression analysis has been done for cement industry for reliability of the result, and the regression output is illustrated in Table 4.2 of Appendices. From the table, it is found that ROA has an insignificant relation with $C R$ and $D R$ in the cement industry. It has the only significant relationship with cash conversion cycle. Return on asset is negatively correlated with the cash conversion cycle, which indicated that if the cash conversion cycle can be reduced, then the ROA will be stronger. In the regression equation, variables having insignificant relationships with the dependent variable have been excluded in this section. Following is the equation with statistically significant variables that resulted out of the test:

\section{ROAc $=0.152-0.002$ CCC}

In the above equation, $C$ denotes cement industry. And, the equation shows that for 1 unit increase in $\mathrm{CCC}$, there will be 0.002 unit decrease in ROA of cement industry. Table 4.2 
depicts that R-square of cement industry is 0.291 , which means the ROA of cement industry varies 0.291 or $29.1 \%$ due to the change in the cash conversion cycle.

\section{DSE-Manufacturing Sector}

Table 5.1 of Appendices shows the correlation matrix for the variables of overall manufacturing sector. Regression analysis has been done here to check whether null hypotheses can be rejected or not. In Table-5.2 of Appendices, regression analysis of overall manufacturing industry has been demonstrated. From the table, it is found that ROA has an insignificant relationship with DR. It has the significant relationships with cash conversion cycle and current ratio. Return on asset is negatively correlated with the cash conversion cycle, which means that shorter the cash conversion cycle, improved is the ROA. There is a positive relationship between ROA and current ratio. The regression equation with variable having insignificant relationship with the dependent variable has been excluded in this section. The equation with statistically significant variables that resulted out of the test is as below:

\section{ROADSEM $=0.102-0.001 \mathrm{CCC}+\mathbf{0 . 0 3 0} \mathrm{CR}$}

In the above equation, DSEM denotes the overall manufacturing industry/DSE listed manufacturing companies of Bangladesh. And, the equation shows that for 1 unit increase in CCC, there will be 0.001 unit decrease in ROA of manufacturing sector and for 1 unit increase in current ratio, ROA will be increased by 0.30 units. Table 5.2 shows that R-square of the manufacturing sector is 0.214 which means the ROA of manufacturing industry varies 0.214 or $21.4 \%$ due to the change in the cash conversion cycle.

\section{CONCLUSIONS AND RECOMMENDATIONS}

Present study finds out that in every industry of Bangladesh, there is a negative but significant relationship between CCC and ROA. This is consistent with many previous studies like Quayyum, 2012; Lazaridis \& Tryfonidis, 2006. In this study, it is also found that there is no significant relationship between ROA and DR in any of the four sampled industries. But the relationship between $\mathrm{ROA}$ and $\mathrm{CR}$ varies from industry to industry. As it has been found that firms with shorter CCC have contribution toward better profitability, therefore a firm can create profit by reducing the CCC. Therefore it is expected that managers can make profit in their companies by proper management of cash conversion cycle and other elements like inventory, accounts receivable, and accounts payable to an optimum level. So, managers need to focus on the working capital management.

\section{Suggestion FOR Future RESEARCH}

In the present study, only 21 companies have been selected as a sample. So, in the future, if all the listed companies are taken, then an overall idea regarding this working capital management can be identified.

\section{LIMITATIONS}

There are several limitations of this study; for example here only 21 companies have been considered. The second limitation is, only a period of five years data has been analyzed for this study. Another limitation is that only four industries have been analyzed. Moreover, the dependent variables are few in number.

\section{REFERENCES}

Cote, J. M., \& Latham, C. K. (1999). The Merchandising Ratio: A Comprehensive Measure of Working Capital Strategy. Issues in Accounting Education, 14(2), 255-267. http:/ / dx.doi.org/10.2308/iace.1999.14.2.255

Deloof, 2003. "Does Working Capital Management Affects Profitability of Belgian Firms?" Journal of Business Finance \& Accounting, Vol 30 No 3 \& 4 pp. $573-587$

Eljelly, A. (2004) Liquidity-Profitability Tradeoff: An empirical Investigation in an Emerging Market, International Journal of Commerce \& Management, Vol 14 No 2 pp.48 - 61

Ganesan, V. (2007). "An Analysis of Working Capital Management Efficiency in Telecommunication Equipment Industry", River Academic Journal, Vol. 3, No. 2, pp 1-10.

Garcia-Teruel P. J., Martinez-Solano P. M. (2007). Effects of Working Capital Management on SME Profitability. International Journal of Managerial Finance, 3, 164-177.

Lazaridis, I., \& Tryfonidis, D. (2006). The relationship between working capital management and profitability of listed companies in the Athens Stock Exchange. SSRN.com. [Online]

Available: http:/ / papers.ssrn.com/sol3/papers.cfm?abstract_id=931591

Long, M.S., Malitz, I.B., \& Ravid, S.A. (1993). Trade Credit, Quality Guarantees, and Product Marketability. Financial Management, 22(4), 117-127. http:/ / dx.doi.org/10.2307/3665582

Quayyum (2012). Relationship between Working Capital Management and Profitability in Context of Manufacturing Industries in Bangladesh. International Journal of Business and Management Vol. 7, No. 1; January 2012

Raheman, A., \& Nasr, M. (2007). Working Capital Management And Profitability - Case Of Pakistani Firms. International Review of Business Research papers, 3(1), 279 - 300.

Scherr, F. C. (1989). Modern Working Capital Management, Text and Cases. Englewood Cliffs, New Jersey: Prentice-Hall International Editions

Shin, H. H., \& Soenen, L. (1998). Efficiency of Working Capital Management and Corporate Profitability, Financial Practice and Education, 8(2), 37-45.

Sial \& Chaudhry (2012). Relationship between Working Capital Management and Firm Profitability Manufacturing Sector of Pakistan

Siddiquee, M. M., \& Khan, S. M. (2008). Analyzing Working Capital Performance: Evidence from Dhaka Stock Exchange (DSE) Ltd. The Journal of Nepalese Business Studies, III(1).

Syaduzzaman, M. (2006). “Working Capital Management: A Study on British American Tobacco Bangladesh Company Limited", The Journal of Nepalese Business Studies, Vol. III, No. 1, pp. 78-84. 


\section{APPENDICES}

Tab1e 1.1: Correlation between ROA and Working capital Ratios of Pharmaceutical Industry

\begin{tabular}{|c|c|c|c|c|c|c|c|c|}
\hline \multicolumn{9}{|c|}{ Correlations } \\
\hline & & ROA & ACP & ITID & APP & $\mathrm{CCC}$ & CR & DR \\
\hline \multirow{2}{*}{$\mathrm{ROA}$} & Pearson Correlation & 1 & & & & & & \\
\hline & Sig. (1-tailed) & & & & & & & \\
\hline \multirow{2}{*}{$\mathrm{ACP}$} & Pearson Correlation & -0.294 & 1 & & & & & \\
\hline & Sig. (1-tailed) & 0.077 & & & & & & \\
\hline \multirow{2}{*}{ ITID } & Pearson Correlation & $-.594^{* *}$ & 0.322 & 1 & & & & \\
\hline & Sig. (1-tailed) & 0.001 & 0.058 & & & & & \\
\hline \multirow{2}{*}{ APP } & Pearson Correlation & 0.079 & 0.136 & $-.351^{*}$ & 1 & & & \\
\hline & Sig. (1-tailed) & 0.354 & 0.259 & 0.043 & & & & \\
\hline \multirow{2}{*}{$\mathrm{CCC}$} & Pearson Correlation & $-.531^{* *}$ & 0.038 & $.713^{* *}$ & -0.334 & 1 & & \\
\hline & Sig. (1-tailed) & 0.003 & 0.429 & 0 & 0.051 & & & \\
\hline \multirow{2}{*}{ CR } & Pearson Correlation & -0.088 & -0.036 & 0.031 & -0.269 & -0.234 & 1 & \\
\hline & Sig. (1-tailed) & 0.338 & 0.432 & 0.442 & 0.097 & 0.131 & & \\
\hline \multirow{2}{*}{ DR } & Pearson Correlation & 0.216 & 0.014 & $-.341^{*}$ & $.416^{*}$ & -0.218 & $-.741^{* *}$ & 1 \\
\hline & Sig. (1-tailed) & 0.15 & 0.474 & 0.048 & 0.019 & 0.148 & 0 & \\
\hline
\end{tabular}

**. Correlation is significant at the 0.01 level (1-tailed).

*. Correlation is significant at the 0.05 level (1-tailed).

Table 1.2: Regression Analysis for ROA of Pharmaceuticals Industry in DSE

\begin{tabular}{|c|c|c|c|}
\hline \multicolumn{4}{|c|}{ Model Summary } \\
\hline Model & R Square & Std. Error of the Estimate & P Value \\
\hline 1 & 0.35 & 0.06317 & $.026^{\mathrm{b}}$ \\
\hline Dependent Variable & Independent Variable & Coefficient & P Value \\
\hline \multirow{3}{*}{ ROA } & CCC & -0.001 & 0.006 \\
\cline { 2 - 4 } & CR & -0.04 & 0.187 \\
\cline { 2 - 4 } & DR & -0.082 & 0.424 \\
\hline
\end{tabular}

Tab1e 2.1: Correlation between ROA and Working capital Ratios of Food Industry

\begin{tabular}{|c|c|c|c|c|c|c|c|c|}
\hline \multicolumn{9}{|c|}{ Correlations } \\
\hline & & ROA & $\mathrm{ACP}$ & ITID & APP & $\mathrm{CCC}$ & CR & DR \\
\hline \multirow[b]{2}{*}{ ROA } & Pearson Correlation & 1 & & & & & & \\
\hline & Sig. (1-tailed) & & & & & & & \\
\hline \multirow[b]{2}{*}{$\mathrm{ACP}$} & Pearson Correlation & -0.228 & 1 & & & & & \\
\hline & Sig. (1-tailed) & 0.136 & & & & & & \\
\hline \multirow[b]{2}{*}{ ITID } & Pearson Correlation & -0.075 & 0.004 & 1 & & & & \\
\hline & Sig. (1-tailed) & 0.361 & 0.493 & & & & & \\
\hline \multirow[b]{2}{*}{ APP } & Pearson Correlation & $.612^{* *}$ & 0.092 & $.395^{*}$ & 1 & & & \\
\hline & Sig. (1-tailed) & 0.001 & 0.331 & 0.025 & & & & \\
\hline \multirow[b]{2}{*}{$\mathrm{CCC}$} & Pearson Correlation & $-.652^{* *}$ & $.444^{*}$ & $.556^{* *}$ & $-.384^{*}$ & 1 & & \\
\hline & Sig. (1-tailed) & 0 & 0.013 & 0.002 & 0.029 & & & \\
\hline \multirow[b]{2}{*}{ CR } & Pearson Correlation & -0.084 & $.772^{* *}$ & -0.312 & -0.123 & 0.221 & 1 & \\
\hline & Sig. (1-tailed) & 0.345 & 0 & 0.065 & 0.279 & 0.144 & & \\
\hline \multirow[b]{2}{*}{ DR } & Pearson Correlation & -0.12 & $-.794^{* *}$ & 0.291 & -0.176 & -0.021 & $-.825^{* *}$ & 1 \\
\hline & Sig. (1-tailed) & 0.284 & 0 & 0.079 & 0.2 & 0.461 & 0 & \\
\hline
\end{tabular}

**. Correlation is significant at the 0.01 level (1-tailed).

*. Correlation is significant at the 0.05 level (1-tailed).

Table 2.2: Regression Analysis for ROA of Food Industry in DSE

\begin{tabular}{|c|c|c|c|}
\hline \multirow{2}{*}{ Model } & R Square & Std. Error of the Estimate & P Value \\
\hline 2 & 0.451 & 0.06739 & $.005 \mathrm{~b}$ \\
\hline Dependent Variable & Independent Variable & Coefficient & P Value \\
\hline \multirow{3}{*}{ ROA } & CCC & -0.001 & 0.002 \\
\cline { 2 - 4 } & CR & -0.034 & 0.57 \\
\cline { 2 - 4 } & DR & -0.16 & 0.363 \\
\hline
\end{tabular}


Tab1e 3.1: Correlation between ROA and Working capital Ratios of Textile Industry

\begin{tabular}{|c|c|c|c|c|c|c|c|c|}
\hline \multicolumn{9}{|c|}{ Correlations } \\
\hline & & ROA & $\mathrm{ACP}$ & ITID & $\mathrm{APP}$ & CCC & CR & DR \\
\hline \multirow[b]{2}{*}{ ROA } & Pearson Correlation & 1 & & & & & & \\
\hline & Sig. (1-tailed) & & & & & & & \\
\hline \multirow[b]{2}{*}{$\mathrm{ACP}$} & Pearson Correlation & $-.364^{*}$ & 1 & & & & & \\
\hline & Sig. (1-tailed) & .037 & & & & & & \\
\hline \multirow[b]{2}{*}{ ITID } & Pearson Correlation & $-.427^{*}$ & -.161 & 1 & & & & \\
\hline & Sig. (1-tailed) & .017 & .222 & & & & & \\
\hline \multirow[b]{2}{*}{$\mathrm{APP}$} & Pearson Correlation & .053 & .091 & -.116 & 1 & & & \\
\hline & Sig. (1-tailed) & .401 & .333 & .291 & & & & \\
\hline \multirow[b]{2}{*}{ CCC } & Pearson Correlation & $-.500^{* *}$ & .057 & $.627^{* *}$ & $-.512^{* *}$ & 1 & & \\
\hline & Sig. (1-tailed) & .005 & .393 & .000 & .004 & & & \\
\hline \multirow[b]{2}{*}{ CR } & Pearson Correlation & $.445^{*}$ & $-.477^{* *}$ & -.066 & $-.446^{*}$ & .270 & 1 & \\
\hline & Sig. (1-tailed) & .013 & .008 & .377 & .013 & .096 & & \\
\hline \multirow[b]{2}{*}{ DR } & Pearson Correlation & -.236 & .129 & .091 & .308 & -.241 & $-.669^{* *}$ & 1 \\
\hline & Sig. (1-tailed) & .128 & .269 & .333 & .067 & .123 & .000 & \\
\hline
\end{tabular}

*. Correlation is significant at the 0.05 level (1-tailed).

**. Correlation is significant at the 0.01 level (1-tailed).

Table 3.2: Regression Analysis for ROA of Textile Industry in DSE

\begin{tabular}{|c|c|c|c|}
\hline \multicolumn{4}{|c|}{ Model Summary } \\
\hline Model & R Square & Std. Error of the Estimate & P Value \\
\hline 3 & 0.614 & 0.04978 & 0.000 \\
\hline Dependent Variable & Independent Variable & Coefficient & P Value \\
\hline \multirow{3}{*}{ ROA } & CCC & -0.001 & 0.000 \\
\cline { 2 - 4 } & CR & 0.062 & 0.002 \\
\cline { 2 - 4 } & DR & 0.015 & 0.829 \\
\hline
\end{tabular}

Tab1e 4.1: Correlation between ROA and Working capital Ratios of Cement Industry

\begin{tabular}{|c|c|c|c|c|c|c|c|c|}
\hline \multicolumn{9}{|c|}{ Correlations } \\
\hline & & ROA & $\mathrm{ACP}$ & APP & ITID & CCC & CR & DR \\
\hline \multirow[b]{2}{*}{ ROA } & Pearson Correlation & 1 & & & & & & \\
\hline & Sig. (1-tailed) & & & & & & & \\
\hline \multirow[b]{2}{*}{$\mathrm{ACP}$} & Pearson Correlation & -0.273 & 1 & & & & & \\
\hline & Sig. (1-tailed) & 0.073 & & & & & & \\
\hline \multirow[b]{2}{*}{$\mathrm{APP}$} & Pearson Correlation & $.317^{*}$ & 0.11 & 1 & & & & \\
\hline & Sig. (1-tailed) & 0.044 & 0.282 & & & & & \\
\hline \multirow[b]{2}{*}{ ITID } & Pearson Correlation & 0.156 & $.576^{* *}$ & $.577^{* *}$ & 1 & & & \\
\hline & Sig. (1-tailed) & 0.205 & 0 & 0 & & & & \\
\hline \multirow[b]{2}{*}{$\mathrm{CCC}$} & Pearson Correlation & $-.524^{* *}$ & 0.164 & $-.788^{* *}$ & $-.313^{*}$ & 1 & & \\
\hline & Sig. (1-tailed) & 0.001 & 0.193 & 0 & 0.046 & & & \\
\hline \multirow[b]{2}{*}{ CR } & Pearson Correlation & 0.21 & -0.021 & 0.045 & $.364^{*}$ & $-.321^{*}$ & 1 & \\
\hline & Sig. (1-tailed) & 0.133 & 0.455 & 0.407 & 0.024 & 0.042 & & \\
\hline \multirow[b]{2}{*}{ DR } & Pearson Correlation & -0.153 & -0.189 & $-.621^{* *}$ & $-.513^{* *}$ & $.492^{* *}$ & -0.155 & 1 \\
\hline & Sig. (1-tailed) & 0.21 & 0.159 & 0 & 0.002 & 0.003 & 0.207 & \\
\hline
\end{tabular}

*. Correlation is significant at the 0.05 level (1-tailed).

**. Correlation is significant at the 0.01 level (1-tailed).

Table 4.2: Regression Analysis for ROA of Cement Industry in DSE-Manufacturing Sector

\begin{tabular}{|c|c|c|c|}
\hline \multicolumn{4}{|c|}{ Model Summary } \\
\hline Model & R Square & Std. Error of the Estimate & P Value \\
\hline 4 & 0.291 & 0.14687 & $.028^{\mathrm{b}}$ \\
\hline Dependent Variable & Independent Variable & Coefficient & P Value \\
\hline \multirow{3}{*}{ ROA } & CCC & -0.002 & 0.007 \\
\cline { 2 - 4 } & CR & 0.008 & 0.794 \\
\cline { 2 - 4 } & DR & 0.111 & 0.471 \\
\hline
\end{tabular}


Tab1e 5.1: Correlation between ROA and Working capital Ratios of DSE- Manufacturing Sector

\begin{tabular}{|c|c|c|c|c|c|c|c|c|}
\hline \multicolumn{9}{|c|}{ Correlations } \\
\hline & & $\mathrm{ROA}$ & $\mathrm{ACP}$ & ITID & APP & CCC & CR & $\overline{D R}$ \\
\hline \multirow[b]{2}{*}{ ROA } & Pearson Correlation & 1 & & & & & & \\
\hline & Sig. (1-tailed) & & & & & & & \\
\hline \multirow[b]{2}{*}{$\mathrm{ACP}$} & Pearson Correlation & $-.213^{*}$ & 1 & & & & & \\
\hline & Sig. (1-tailed) & .015 & & & & & & \\
\hline \multirow[b]{2}{*}{ ITID } & Pearson Correlation & $-.223^{*}$ & $.239^{* *}$ & 1 & & & & \\
\hline & Sig. (1-tailed) & .011 & .007 & & & & & \\
\hline \multirow[b]{2}{*}{$\mathrm{APP}$} & Pearson Correlation & $.216^{*}$ & .087 & -.094 & 1 & & & \\
\hline & Sig. (1-tailed) & .013 & .187 & .171 & & & & \\
\hline \multirow[b]{2}{*}{$\mathrm{CCC}$} & Pearson Correlation & $-.397^{* *}$ & .119 & $.641^{* *}$ & $-.613^{* *}$ & 1 & & \\
\hline & Sig. (1-tailed) & .000 & .113 & .000 & .000 & & & \\
\hline \multirow[b]{2}{*}{ CR } & Pearson Correlation & $.234^{* *}$ & -.055 & -.023 & $-.203^{*}$ & .007 & 1 & \\
\hline & Sig. (1-tailed) & .008 & .289 & .406 & .019 & .471 & & \\
\hline \multirow[b]{2}{*}{ DR } & Pearson Correlation & -.117 & -.068 & -.103 & -.024 & -.085 & $-.564^{* *}$ & 1 \\
\hline & Sig. (1-tailed) & .117 & .245 & .147 & .406 & .195 & .000 & \\
\hline
\end{tabular}

*. Correlation is significant at the 0.05 level (1-tailed).

**. Correlation is significant at the 0.01 level (1-tailed).

Table 5.2: Regression Analysis for ROA of DSE-Manufacturing Sector

\begin{tabular}{|c|c|c|c|}
\hline \multicolumn{4}{|c|}{ Model Summary } \\
\hline Model & R Square & Std. Error of the Estimate & P Value \\
\hline 4 & 0.214 & 0.10025 & $.000^{\mathrm{b}}$ \\
\hline Dependent Variable & Independent Variable & Coefficient & P Value \\
\hline \multirow{3}{*}{ ROA } & CCC & -0.001 & 0.000 \\
\cline { 2 - 4 } & CR & 0.03 & 0.041 \\
\cline { 2 - 4 } & DR & -0.014 & 0.808 \\
\hline
\end{tabular}




\section{SOCIAL SCIENCE RESEARCH NETWORK}

2171 Monroe Avenue, Suite 203, Rochester, NY 14618, USA

http://www.ssrn.com/en/

AJTP Link: http://www.ssrn.com/link/American-Journal-Trade-Policy.html 